\title{
EOFAZ inhibits endothelial-to-mesenchymal transition through downregulation of KLF4
}

\author{
YANYAN ZHANG ${ }^{1-3^{*}},{\text { CHEN } \mathrm{LI}^{2,3^{*}} \text {, YONGPAN HUANG }}^{1 *}$, SHUANG ZHAO ${ }^{1-3}$, YINI XU $^{1-3}$, \\ YAN CHEN $^{2-4}$, FENG JIANG ${ }^{2-4}$, LING TAO ${ }^{2,3}$ and XIANGCHUN SHEN ${ }^{1-4}$

\begin{abstract}
${ }^{1}$ The State Key Laboratory of Functions and Applications of Medicinal Plants, School of Basic Medical Sciences, Guizhou Medical University; ${ }^{2}$ Department of Clinical Pharmacy, School of Pharmaceutical Sciences, Guizhou Medical University; ${ }^{3}$ Department of Pharmacology of Materia Medica, Guizhou Medical University;

${ }^{4}$ The Key Laboratory of Optimal Utilization of Natural Medicine Resources, School of Pharmaceutical Sciences, Guizhou Medical University, Guiyang, Guizhou 550025, P.R. China
\end{abstract}

Received July 11, 2019; Accepted March 11, 2020

DOI: $10.3892 /$ ijmm.2020.4572

\begin{abstract}
Essential oil from Alpinia zerumbet rhizome (EOFAZ), which is termed Yan shanjiang in China, is extensively used as an herbal medicine in the Guizhou area and has been shown to protect against the damaging effects of cardiovascular injury in vitro and in vivo. In the present study, it was hypothesized that the protective effects of EOFAZ on transforming growth factor (TGF)- $\beta 1$-induced endothelial-to-mesenchymal transition (EndMT) in human umbilical vein endothelial cells (HUVECs) were mediated by inhibition of Krüppel-like factor 4 (KLF4). Cell motility was assessed using wound healing and Transwell assays. The expression of endothelial markers and mesenchymal markers were determined by reverse transcription-quantitative PCR, immunofluorescence staining and western blotting, and additionally, phosphorylated $\mathrm{NF}-\kappa \mathrm{B}$ p65 expression was determined by western blotting. Furthermore, the involvement of KLF4 in EndMT was determined using RNA interference to knockdown the expression of KLF4. TGF- $\beta 1$ treatment significantly promoted EndMT, as evidenced by downregulation of vascular endothelial-cadherin and upregulation of $\alpha$-smooth muscle actin in HUVECs, and by enhancing cell migration. Small interfering RNA-mediated knockdown of KLF4 reversed TGF- $\beta 1$-induced EndMT. Additionally,
\end{abstract}

Correspondence to: Professor Xiangchun Shen, The State Key Laboratory of Functions and Applications of Medicinal Plants, School of Basic Medical Sciences, Guizhou Medical University, 1 Dongqing Road, Guian New District, Guiyang, Guizhou 550025, P.R. China

E-mail: shenxiangchun@126.com

${ }^{*}$ Contributed equally

Key words: essential oil from Alpinia zerumbet rhizome, human umbilical vein endothelial cells, transforming growth factor- $\beta 1$, endothelial-to-mesenchymal transition, Krüppel-like factor 4 treatment with EOFAZ inhibited TGF- $\beta 1$-induced EndMT in a dose-dependent manner. These results suggest that TGF- $\beta 1$ may induce EndMT through upregulation of KLF4, and this may be reversed by EOFAZ. Therefore, EOFAZ was shown to inhibit TGF- $\beta 1$-induced EndMT through regulation of KLF4.

\section{Introduction}

The vascular wall consists of endothelial cells, smooth muscle cells, fibroblasts and extracellular matrix, and is considered an active and integrated organ (1). The vasculature is sensitive to a range of stimuli, several of which may contribute to pathophysiological changes in response to stresses that result in proliferation of the vasculature (2). The initiating event in vascular remodeling is endothelial cell damage. Alterations in the presence of vasoactive substances following endothelial cell dysfunction are involved in the development and progress of cardiovascular diseases. A vicious circle is caused by further injury of endothelial cells following the onset of cardiovascular diseases (3). This dynamic process characterizes vascular remodeling, and is defined as any enduring change in the size and/or composition of an adult blood vessel that allows blood vessels to adapt and heal (4). Vascular remodeling underlies the pathogenesis of major cardiovascular disorders, including pulmonary arterial hypertension (PAH) and atherosclerosis, as well as wound healing (5). Vascular remodeling is involved in cells progressing through four cellular processes: Differentiation, death, migration, and production or degradation of extracellular matrix $(3,6)$. Endothelial cells are pivotal in the initiation of vascular remodeling. The increase in mesenchymal or smooth muscle (SM)-like phenotypes originates from increased endothelial cell transformation (7). Endothelial cells are the first barrier of blood vessels and recently they have been regarded as contributors to vascular remodeling through endothelial-to-mesenchymal transition (EndMT) (8).

EndMT is the process by which endothelial cells undergo phenotypic changes and acquire a mesenchymal/SM-like phenotype (9). Under pathophysiological conditions, such as transplant atherosclerosis and restenosis, endothelial-derived mesenchymal cells may accelerate the development of 
neointimal lesions (10). Evidence for EndMT has been demonstrated in the context of cardiac and vascular development, wound healing and various dysfunctions, including tissue fibrosis and diabetic nephropathy (11). Thus, EndMT is regarded as an important mechanism for the generation of SM-like cells. Endothelial cells facilitate vascular development and dysfunction, which act through direct and indirect roles in the vascular remodeling process (12). A previous study has demonstrated that EndMT is involved in the pathogenesis of vascular remodeling (13). EndMT contributes to neointimal formation in interpositional vein grafts (14). Similarly, EndMT contributes to intimal hyperplasia and early-lesion formation in atherosclerosis (15). Furthermore, EndMT contributes to progression of PAH, atherosclerosis and wound healing (16). Therefore, in the present study, it was hypothesized that EndMT may accelerate the pathogenesis of vascular remodeling. However, the role of EndMT and the mechanisms regulating cell phenotype adaption during vascular remodeling are poorly understood. Studies have reported that mouse and human endothelial cells are induced by transforming growth factor (TGF)- $\beta 1$ to transform into SM-like cells in which the expression of $\alpha$-smooth muscle actin ( $\alpha$-SMA) is upregulated $(17,18)$. Under the synergistic action of TGF- $\beta 1$ and the Wnt signaling pathway, EndMT may be induced. Therefore, in the present study, TGF- $\beta 1$ was used to develop an in vitro model of EndMT (19).

Zingiberaceae belongs to the ginger family, which consists of a large number of aromatic perennial species shown to exhibit therapeutic potential in a number of cardiac-related therapies (20). Alpinia zerumbet (Pers.) Burtt et Smith, termed Yan Shanjiang in China, is an aromatic plant originating in the East Indies and is widely used as an herbal medicine in South America, Oceania and Asia $(21,22)$. It contains several bioactive constituents and possesses a broad spectrum of pharmacological properties, such as antihypertensive, anti-inflammatory and cardiovascular protective effects, as well as antioxidant effects $(23,24)$, and is widely used as a local Miao herbal medicine in the Guizhou province. Previous studies have shown that essential oil from Alpinia zerumbet rhizome (EOFAZ) is effective against the vasoconstriction induced by release of norepinephrine and $\mathrm{KCl}$ (25). The mechanisms mediating the beneficial effects of EOFAZ may include inhibition of oxidative stress and inflammation, and induction of apoptosis (26). However, the effects of EOFAZ on EndMT in a range of stress situations has not been investigated, particularly in relation to TGF- $\beta 1$ signaling (22).

In the present study, a cell based in vitro model treated with TGF- $\beta 1$ was established to verify the hypothesis that EOFAZ protects against TGF- $\beta 1$-induced EndMT, and to determine the underlying molecular mechanism by which EOFAZ exerts its beneficial effects. The present study identified a novel molecular mechanism by which EOFAZ exerts its effects and also provides a theoretical basis for use of EOFAZ treatment for cardiac disorders.

\section{Materials and methods}

Extraction of EOFAZ. The essential oil was extracted from the fruit of Alpinia zerumbet, which was collected in Zhenfeng County, Guiyang, China, in October 2018. The fruit was identified by Professor Qingde Long (Department of Pharmacognosy and Medico-botany, Guizhou Medical University, Guiyang, China) and a voucher specimen (no. 20181029) was deposited to the Key Laboratory of Optimal Utilization of Natural Medicinal Resources, Guizhou Medical University. The method of extraction/isolation and the compounds of EOFAZ were identified according to our previous study (22).

Cell culture. Human umbilical vein endothelial cells (HUVECs) were purchased from The Cell Bank of Type Culture Collection of the Chinese Academy of Sciences. Cells were cultured in Endothelial Cell Medium (ScienCell Research Laboratories, Inc.) supplemented with 5\% FBS (ScienCell Research Laboratories, Inc.) and $100 \mathrm{U} / \mathrm{ml}$ penicillin and streptomycin, and maintained in an incubator at $37^{\circ} \mathrm{C}$ with $5 \% \mathrm{CO}_{2}$. Cells were sub-cultured and seeded into 6- or 24-well plates for subsequent experiments as required. The cells were pretreated with EOFAZ and LY2109761 (Selleck Chemicals) for $2 \mathrm{~h}$ at $37^{\circ} \mathrm{C}$, and TGF- $\beta 1$ (Peprotech EC Ltd.) was added for $72 \mathrm{~h}$. HUVECs were trypsinized with $0.25 \%$ trypsin and collected for analysis.

Cell morphological assessment. The HUVECs were plated in 6 -well plates at a density of $3 \times 10^{5}$ cells/well and were incubated overnight. Following treatment with $10 \mathrm{ng} / \mathrm{ml}$ TGF- $\beta 1$ for $72 \mathrm{~h}$ at $37^{\circ} \mathrm{C}$, the cultured plates were examined and photographs were obtained using an inverted light microscope (magnification, x100).

Western blot analysis. Cells were lysed in RIPA lysis buffer containing protease inhibitors (Beyotime Institute of Biotechnology). The protein concentration was determined by BCA assay. For western blotting, a total of $40 \mu \mathrm{g}$ protein/lane from lysed cells was separated by $10 \%$ SDS-PAGE. The proteins were transferred to a PVDF membrane and the membrane was blocked with $5 \%$ non-fat dry milk at room temperature $\left(25^{\circ} \mathrm{C}\right)$ for $2 \mathrm{~h}$. The membrane was then incubated with the following primary antibodies overnight at $4^{\circ} \mathrm{C}$ : Rabbit anti-Krüppel-like factor 4 (KLF4; 1:1,000; cat. no. 12173S), anti-vascular endothelial (VE)-cadherin (1:1,000; cat. no. 2500), anti- $\alpha$-SMA (1:1,000; cat. no. 19245), anti-snail (1:1,000; cat. no. 5276) and

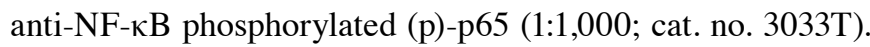
All primary antibodies were from Cell Signaling Technology, Inc. and all were diluted in TBS and 0.2\% Tween-20. Subsequently, the membranes were washed and incubated with a horseradish peroxidase-conjugated secondary antibody (Cell Signaling Technology, Inc.; 1:10,000; cat. no. 7076) for $90 \mathrm{~min}$ at room temperature. Signals were visualized using an ECL kit (GE Healthcare). The expression levels of protein were calculated by using ImageJ V1.8.0.112 software (National Institutes of Health). Protein signals were normalized to $\beta$-actin (Cell Signaling Technology, Inc.; 1:1,000; cat. no. 3700).

Reverse transcription-quantitative $(R T-q) P C R$. Total RNA was extracted using the TransZol Up Plus RNA kit (Sangon Biotech Co., Ltd.). Total RNA was purified with $75 \%$ ethanol and its concentration was determined using spectrophotometry. cDNA was synthesized from the purified RNA (200 ng per sample) using a reverse transcription kit (cat. no. DRR037A; 
Takara Bio, Inc.), according to the manufacturer's protocol. Subsequently, qPCR was performed on an ABI 7300 Real-Time PCR system SYBR Premix ExTaq (Takara Bio, Inc.). The thermocycling conditions were as follows: Pre-incubation at $94^{\circ} \mathrm{C}$ for $30 \mathrm{sec}$ followed by 39 cycles of amplification at $94^{\circ} \mathrm{C}$ for $5 \mathrm{sec}$ and $56^{\circ} \mathrm{C}$ for $30 \mathrm{sec}$. The sequences of the primers were: Vascular endothelial (VE)-cadherin forward, 5'-CTT CACCCAGACCAAGTACACA-3' and reverse, 5'-AGGGCT CATGTATCGGAGGT-3'; $\alpha$-SMA forward, 5'-ACCATCGGG AATGAACGCTT-3' and reverse, 5'-CTGTCAGCAATGCCT GGGTA-3'; snail forward, 5'-GAAGATGCACATCCGAA GCC-3' and reverse, 5'-TTCACATCCGAGTGGGTCTG-3'; and GAPDH forward, 5'-TGTGAACGGATTTGGCCGTA-3' and reverse, 5'-GATGGTGATGGGTTTCCCGT-3'. GAPDH was used as the loading control.

Immunofluorescence staining. Cells at a density of $1 \times 10^{4} / \mathrm{ml}$ were seeded onto slides and fixed with $4 \%$ paraformaldehyde (200 $\mu \mathrm{l} /$ well) for $10 \mathrm{~min}$, and washed twice with PBS, $10 \mathrm{~min}$ each time. The cell membrane was treated with $0.1 \%$ Triton $\mathrm{X}-100$ in PBS $(200 \mu \mathrm{l} /$ well) at room temperature for $10 \mathrm{~min}$, and then washed twice with PBS, 10 min each time. The plates were agitated gently several times by hand to drain the liquid and cells were then blocked with $4 \%$ goat serum in PBS at room temperature for $30 \mathrm{~min}$. The liquid was gently removed, anti-VE-cadherin and anti- $\alpha$-SMA primary antibodies were added, and the cells were incubated at $37^{\circ} \mathrm{C}$ for $1 \mathrm{~h}$ or at $4^{\circ} \mathrm{C}$ overnight. The primary antibodies used were: Anti-VE-cadherin (1:100; Cell Signaling Technology, Inc.; cat. no. 2500) and anti- $\alpha$-SMA (1:100, Cell Signaling Technology, Inc.; cat. no. 19245). DAPI (1:1,000; Sigma-Aldrich; Merck $\mathrm{KGaA}$; cat. no. AC23192) was used to stain the nuclei at room temperature for $10 \mathrm{~min}$. Subsequently, the cells were washed three times with PBS and then incubated with fluorescein-labeled secondary antibodies (Cell Signaling Technology, Inc.; 1:100; cat. nos. 4416 and 12877) at $37^{\circ} \mathrm{C}$ for $60 \mathrm{~min}$. Following washing with $0.01 \mathrm{M}$ PBS three times, 5 min per wash, anti-fade reagent was used to mount the slides at $4^{\circ} \mathrm{C}$. Finally, cells were imaged using a fluorescence microscope (magnification, x200).

Wound healing assay. HUVECs were seeded in 24-well plates and grown overnight to confluence. For EndMT induction, cells were treated with $10 \mathrm{ng} / \mathrm{ml}$ TGF- $\beta 1,2 \mu \mathrm{M}$ LY21097612 and $0.25,1$ or $4 \mu \mathrm{g} / 1 \mathrm{EOFAZ}$ for $72 \mathrm{~h}$ at $37^{\circ} \mathrm{C}$. The monolayer of cells was scratched using a $20-\mu 1$ pipette tip to create the wound. Floating cells were removed by washing twice with PBS and serum-free Endothelial Cell Medium was added. Wound closure rate was assessed using images captured with a light microscope (Leika DM3000k magnification, $\mathrm{x} 100)$ after $24 \mathrm{~h}$. The motility index $=($ Mean of $0 \mathrm{~h}$ migration distance-mean of $12 \mathrm{~h}$ migration distance)/mean of $0 \mathrm{~h}$ migration distance.

Transwell migration assay. Cells were trypsinized, centrifuged at $150 \mathrm{x}$ g for $5 \mathrm{~min}$ at room temperature, washed with PBS 1-2 times and resuspended in serum-free culture medium containing BSA. A cell suspension of $100 \mu \mathrm{l}\left(2 \times 10^{4}\right.$ cells $)$ was added to the upper chamber of the Transwell insert, and $400 \mu \mathrm{l}$ medium containing $10 \%$ FBS was added to the lower chamber.
The cells were cultured for $12 \mathrm{~h}$, after which the Transwell chamber was removed, the medium was discarded, and cells were washed twice with PBS and fixed with paraformaldehyde for $15 \mathrm{~min}$ at room temperature. Subsequently, the cells were stained for $10 \mathrm{~min}$ with $0.1 \%$ crystal violet at room temperature. The unmigrated cells in the upper layer were gently removed with a cotton swab and the chamber was then washed three times with PBS. Cells were observed under an inverted light microscope (magnification, x100) and the number of cells in five randomly chosen fields were counted. The number of migrated cells was quantified by manual counting, and the motility index was determined using the following formula: Motility index=the number of migrated cells in the experimental group/the number of cells that migrated in the control group.

Immunoprecipitation. HUVECs were harvested $72 \mathrm{~h}$ after treatment with TGF- $\beta 1$ or EOFAZ at $37^{\circ} \mathrm{C}$ for $2 \mathrm{~h}$, the supernatant was removed, the cells were lysed with NP-40 lysis buffer (Beyotime Institute of Biotechnology) containing protease inhibitors, and the lysate was centrifuged on ice at $12,000 \mathrm{xg}$ for $30 \mathrm{~min}$ at $4^{\circ} \mathrm{C}$. A small quantity of lysate was used for western blotting, and $1 \mu \mathrm{g}$ antibody (anti-KLF4; 1:200; Cell Signaling Technology, Inc.; cat. no. 12173S) was added to the remaining cell lysate and incubated overnight at $4{ }^{\circ} \mathrm{C}$ with gentle agitation. A total of $10 \mu \mathrm{l}$ protein A agarose beads were washed with lysis buffer and centrifuged at $300 \mathrm{x}$ g for $3 \mathrm{~min}$ at $4^{\circ} \mathrm{C}$. The washed protein $\mathrm{A}$ agarose beads were then added to the cell lysate-antibody solution and incubated at $4^{\circ} \mathrm{C}$ with gentle agitation for 2-4 h. Following immunoprecipitation, agarose beads were pelleted by centrifugation at $300 \mathrm{x} \mathrm{g}$ for $3 \mathrm{~min}$ at $4^{\circ} \mathrm{C}$. The supernatant was aspirated, and the agarose beads were washed 3-4 times with $1 \mathrm{ml}$ lysis buffer. Finally, $15 \mu 12 x$ SDS sample buffer was added, and the samples were boiled for $5 \mathrm{~min}$. Samples were subsequently subjected to western blotting, as previously described.

Small interference (si)RNA transfection. HUVECs were plated in 6-well plates at a density of $2 \times 10^{6}$ cells/well and transfected with siRNA. Briefly, $5 \mu \mathrm{l} \mathrm{KLF4}$ and control siRNA was mixed with RPMI-1640 media (Wisent, Inc.). Lipofectamine ${ }^{\circledR} 2000$ (Invitrogen; Thermo Fisher Scientific, Inc.) was mixed with the RPMI-1640 media and the mixture was left to stand for $20 \mathrm{~min}$ at room temperature. The Lipofectamine ${ }^{\circledR}$-siRNA mixture was then added to each well containing cells and the cells were incubated for $6 \mathrm{~h}$. Medium was then replaced with antibiotic-free Endothelial Cell Medium supplemented with 5\% FBS for $24 \mathrm{~h}$, after which cells were used for subsequent experiments. The KLF4 siRNA sequences were: Sense 5'-AGAGTTCCCATC TCAAGGCA-3' and antisense, 5'-GTCAGTTCATCTGAG CGGG-3'. The sequences of the control non-specific siRNA were: Sense 5'-CGUUUGUUCGCUUCCUGAGTT-3' and antisense, 5'-CUCAGGAAGCGAACAAACGTG-3'.

Statistical analysis. All data are expressed as the mean \pm standard deviation of at least three repeats. SPSS v.21.0 (IBM, Corp.) was used for statistical analysis. Comparisons among multiple groups were analyzed using one-way analysis of variance followed by Bonferroni's post hoc test. Comparisons between two groups were analyzed using a 

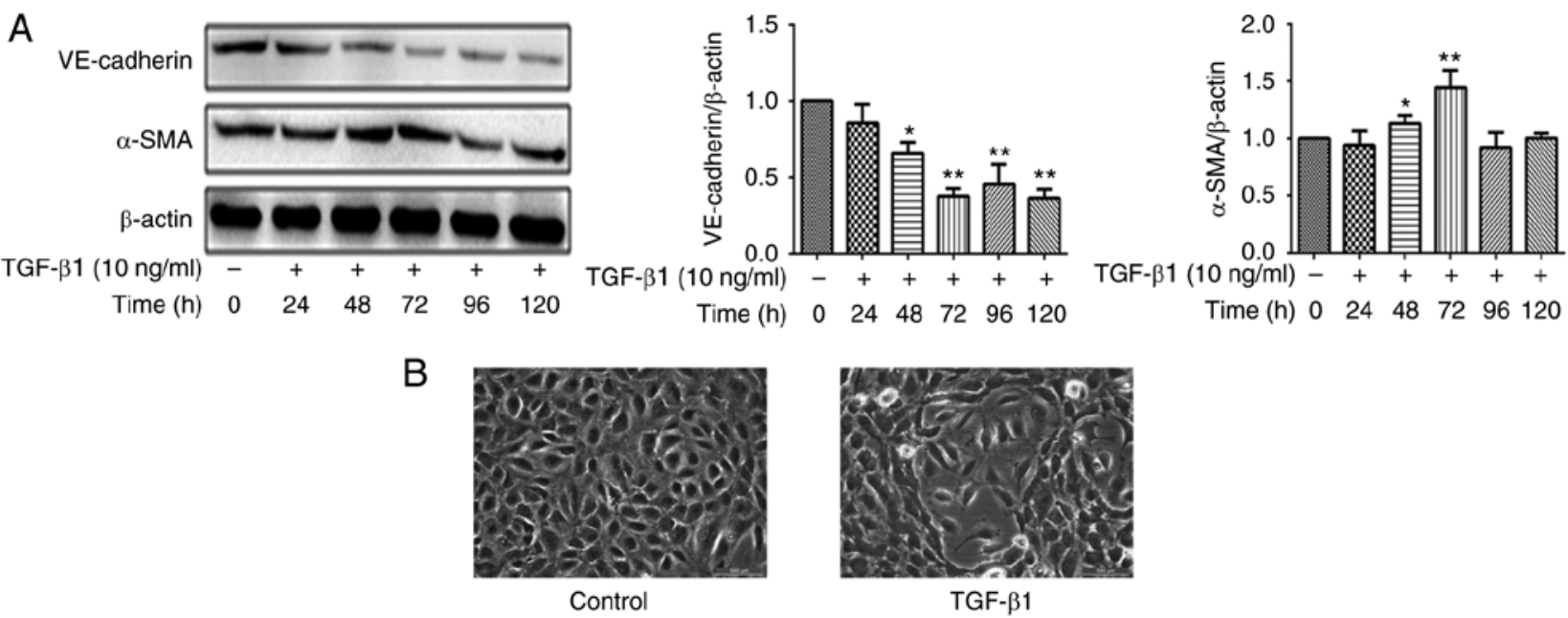

Figure 1. EndMT is induced by TGF- $\beta 1$ in HUVECs. (A) Effect of $10 \mathrm{ng} / \mathrm{ml}$ TGF- $\beta 1$ on cell phenotypic markers at different times. (B) Untreated HUVECs exhibited a cobble-stone like morphology under the light microscope and TGF- $\beta 1$-treated HUVECs acquired a fibroblast-like morphology. Magnification, $\mathrm{x} 400 . \mathrm{n}=3 .{ }^{*} \mathrm{P}<0.05,{ }^{* *} \mathrm{P}<0.01$ vs. control. EndMT, endothelial-to-mesenchymal transition; TGF- $\beta 1$, transforming growth factor- $\beta 1$; HUVEC, human umbilical vein endothelial cell; EndMT, endothelial-to-mesenchymal transition; VE-cadherin, vascular endothelial-cadherin; $\alpha$-SMA, $\alpha$-smooth muscle actin.

two-tailed Student's t-test. $\mathrm{P}<0.05$ was considered to indicate a statistically significant difference.

\section{Results}

EndMT is induced by TGF- $\beta 1$ in HUVECs. TGF- $\beta 1$ is a powerful factor for induction of EndMT, although the effect depends of the treatment time and dose in different models (17). Relative VE-cadherin and $\alpha$-SMA expression levels were determined by western blotting. After cells were treated in Endothelial Cell Medium with or without $10 \mathrm{ng} / \mathrm{ml}$ of TGF- $\beta 1$, the expression levels of VE-cadherin and $\alpha$-SMA changed in a time-dependent manner. As presented in Fig. 1A, the HUVECs were treated with $10 \mathrm{ng} / \mathrm{ml}$ TGF- $\beta 1$ for various durations, and the VE-cadherin and $\alpha$-SMA levels were most significantly changed at $72 \mathrm{~h}$, thus treatment with $10 \mathrm{ng} / \mathrm{ml}$ TGF- $\beta 1$ for $72 \mathrm{~h}$ was selected to establish the EndMT model in following experiments. In addition, the morphological EndMT-associated changes in HUVECs by TGF- $\beta 1$ treatment for $72 \mathrm{~h}$ were observed using an inverted microscope (Fig. 1B). Cells in the control group demonstrated a cobble-stone like morphology and the junctions between the cells were dense. The cells induced by TGF- $\beta 1$ were primarily fibroblast in morphology, the distance between cells was increased, and additionally the presence of filamentous pseudopod protrusions was observed. Taken together, TGF- $\beta 1$ induced morphological and phenotypic changes in HUVECs to a more mesenchymal-like phenotype, suggesting the cells had undergone EndMT and an EndMT model had been established.

EOFAZ inhibits TGF- $\beta 1$-induced EndMT in HUVECs. Subsequently, HUVECs were exposed to $10 \mathrm{ng} / \mathrm{ml}$ TGF- $\beta 1$ for $72 \mathrm{~h}$ for EndMT induction. Additionally, the cells were pretreated with EOFAZ and LY2109761 (a TGF- $\beta 1$ inhibitor) for $2 \mathrm{~h}$ and then stimulated with TGF- $\beta 1$. The results of RT-qPCR and western blotting analysis demonstrated that EOFAZ, like LY2109761, significantly reversed the TGF- $\beta 1$-iduced increase in $\alpha$-SMA and Snail expression and the TGF- $\beta 1$-induced decrease in VE-cadherin expression (Fig. 2A and B). Similar changes were observed by immunofluorescence (Fig. 2C).

EOFAZ inhibits the expression of EndMT markers in cell migration. During the EndMT process initiated in endothelial cells, the cellular migratory ability is promoted (14). A wound healing assay was used to observe the effects of EOFAZ on the migration of endothelial cells treated with TGF- $\beta 1$. The results demonstrated that the cell migration rate significantly increased in the TGF- $\beta 1$-treated group compared with the control group. In addition, scratch immunofluorescence staining demonstrated that VE-cadherin was downregulated, while $\alpha$-SMA was upregulated in the migrating cells after TGF- $\beta 1$ treatment. The number of migrated cells was significantly reduced in cells pre-treated with LY2109761 and EOFAZ, and the expression of VE-cadherin was increased and the expression of $\alpha$-SMA was decreased compared with the cells only treated with TGF- $\beta 1$ (Fig. 3A and B). These results suggest that the TGF- $\beta 1$-induced EndMT is associated with the enhanced migratory capacity of mesenchymal cells, whereas EOFAZ inhibits this migratory capacity.

Effect of EOFAZ on the expression of KLF4 and $N F-\kappa B$ $p-p 65$, and on the binding between KLF4 and NF- $\kappa B$ induced by TGF- $\beta 1$ in HUVECs. As presented in Fig. 3C and D, KLF4 and NF- $\kappa \mathrm{B}$ p-p65 expression levels were upregulated in the TGF- $\beta 1$-induced cells compared with the control. The p-p65/p65 ratio is appropriate to evaluate the activation of NF- $\kappa \mathrm{B}$ (27). The results demonstrated that EOFAZ and LY2109761 significantly decreased the TGF- $\beta 1$-induced increase in p-p65/p65 ratio, which indicated the inhibitory effects of EOFAZ on NF- $\mathrm{NB}$ nuclear translocation and activation. The TGF- $\beta 1$-induced increase in KLF4 was also decreased in the presence of EOFAZ or LY2109761 (Fig. 3C and D). These results suggested that EOFAZ inhibits TGF- $\beta 1$-induced KLF4 and NF- $\kappa \mathrm{B}$ activation. A previous study reported that $\mathrm{NF}-\kappa \mathrm{B}$ is one of key regulators during EndMT in endothelial cells; activation or inhibition of the $\mathrm{NF}-\kappa \mathrm{B}$ signaling pathway 

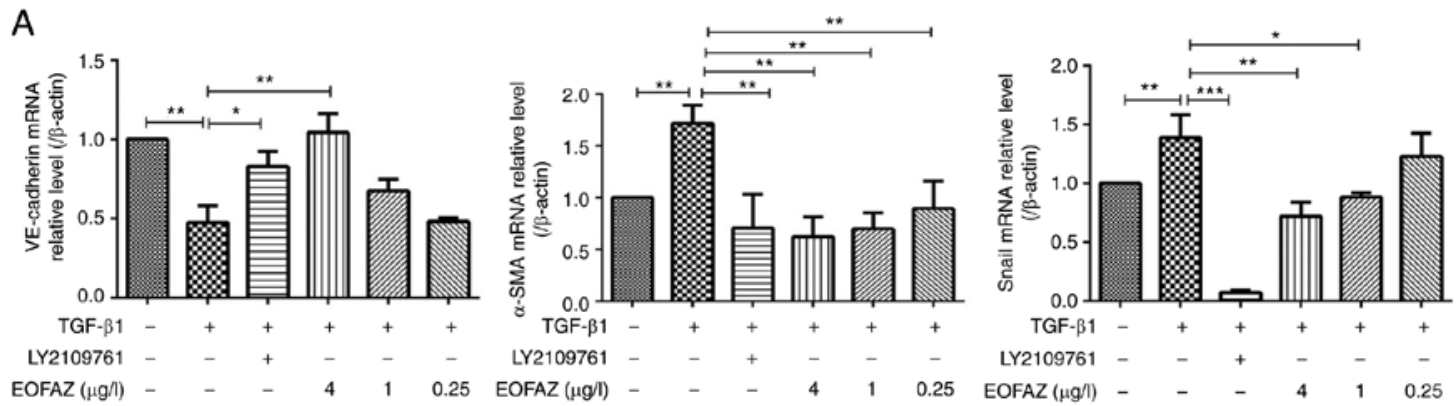

B
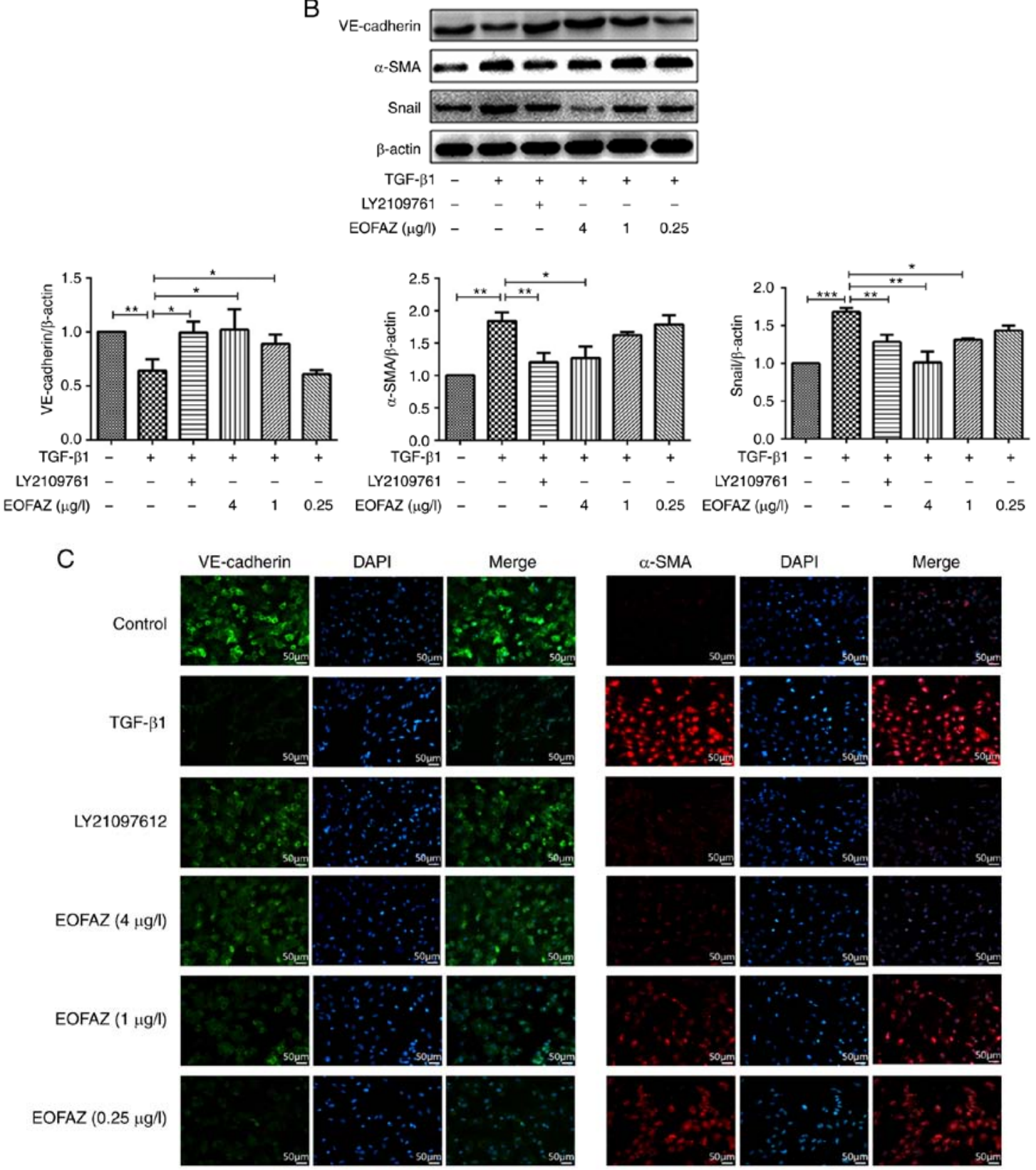

Figure 2. EOFAZ inhibits TGF- $\beta 1$-induced EndMT in HUVECs. (A) Effect of EOFAZ on the mRNA expression levels of VE-cadherin, $\alpha$-SMA and Snail, as measured by RT-qPCR and normalized to $\beta$-actin. $n=5$. (B) Western blots of VE-cadherin, $\alpha$-SMA and Snail. $\beta$-actin was used as the loading control. (C) Immunofluorescence of endothelial marker protein VE-cadherin (green fluorescence), mesenchymal marker protein $\alpha$-SMA (red fluorescence) and nuclei (DAPI, blue). ${ }^{*} \mathrm{P}<0.05,{ }^{* *} \mathrm{P}<0.01,{ }^{* * *} \mathrm{P}<0.001$. EOFAZ, essential oil from Alpinia zerumbet rhizome; EndMT, endothelial-to-mesenchymal transition; TGF- $\beta 1$, transforming growth factor- $\beta 1$; HUVEC, human umbilical vein endothelial cell; $\alpha$-SMA, $\alpha$-smooth muscle actin; VE-cadherin, vascular endothelial-cadherin.

resulted in EndMT reversal (28). In addition, it has been reported that $\mathrm{NF}-\kappa \mathrm{B}$ is essential for both the induction and maintenance of EndMT (29).
A previous study suggested that KLF4 inhibits TNF- $\alpha$-mediated induction of vascular cell adhesion protein 1 (VCAM1) expression by blocking the binding of p65 to the 
A
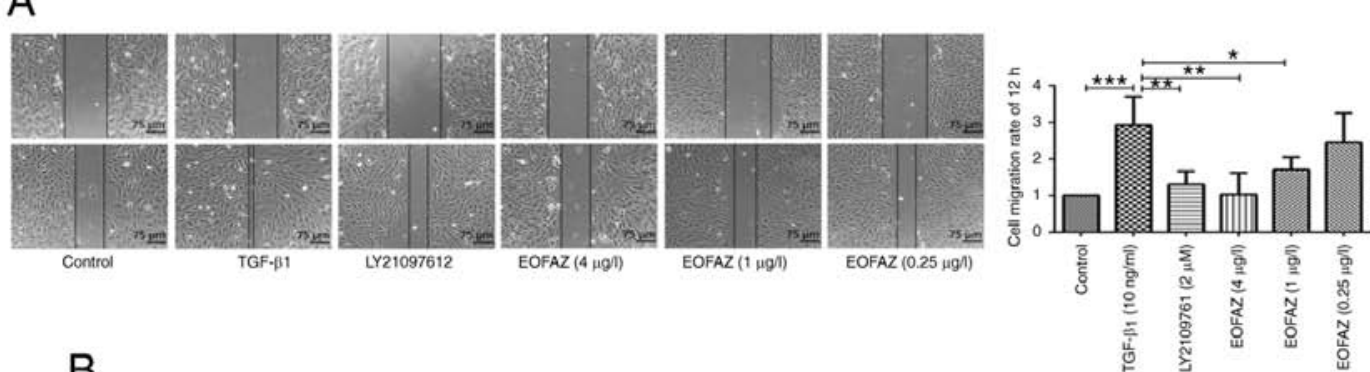

C

B
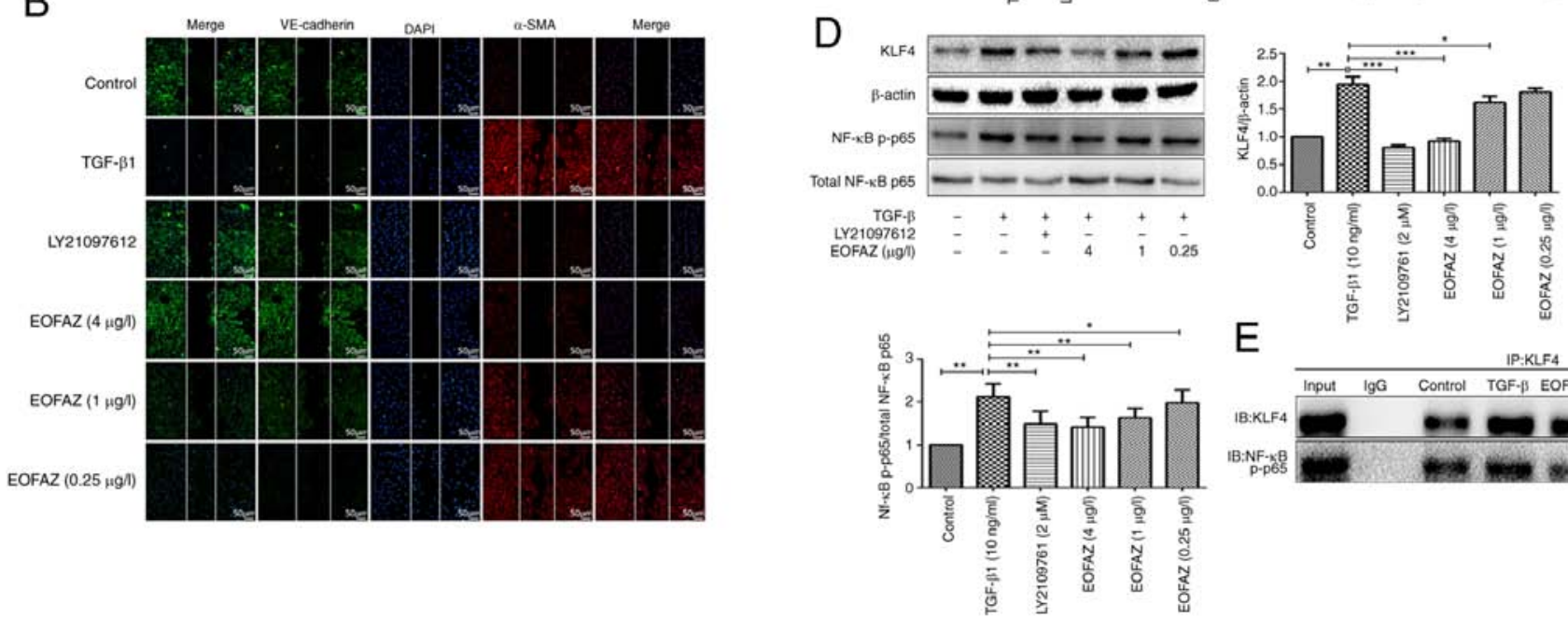

$\mathrm{E}$
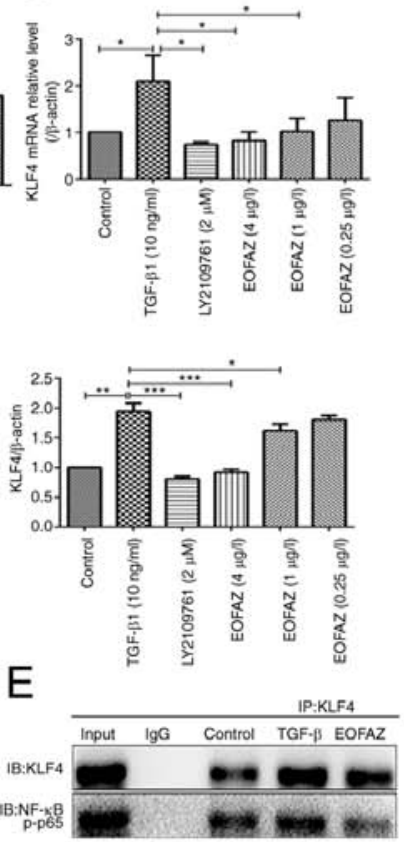

Figure 3. EOFAZ inhibits HUVECs migration and regulates biomarkers in TGF- $\beta 1$-induced EndMT. (A) Wound healing assay of HUVECs treated with TGF- $\beta 1$ and EOFAZ for the indicated time intervals. (B) A wound healing assay was used to observe the effects of EOFAZ on the migration of endothelial cells. Endothelial marker protein VE-cadherin (green fluorescence), mesenchymal marker protein $\alpha$-SMA (red fluorescence) and nuclei (DAPI, blue). (C) Reverse transcription-quantitative PCR analysis of the mRNA expression of KLF4 in HUVECs treated with TGF- $\beta 1$ and EOFAZ. (D) Western blot analysis was performed with treated HUVECs to analyze the expression of KLF4 and NF- $\kappa \mathrm{B}$ p-p65. $\beta$-actin was used as the loading control. (E) Detection of the interaction between KLF4 and NF- $\kappa$ B by co-immunoprecipitation. ${ }^{*} \mathrm{P}<0.05,{ }^{* *} \mathrm{P}<0.01,{ }^{* * *} \mathrm{P}<0.001$. EOFAZ, essential oil from Alpinia zerumbet rhizome; EndMT, endothelial-to-mesenchymal transition; TGF- $\beta 1$, transforming growth factor- $\beta 1$; HUVEC, human umbilical vein endothelial cell; -, phosphorylated; KLF4, Krüppel-like factor 4; $\alpha$-SMA, $\alpha$-smooth muscle actin; VE-cadherin, vascular endothelial-cadherin.

VCAM1 promoter through the physical association between KLF4 and p65 (30-32). Therefore, the present study hypothesized that KLF4 similarly regulates the activation of $\mathrm{NF}-\kappa \mathrm{B}$ in the TGF- $\beta 1$-induced EndMT process. To confirm binding between KLF4 and NF- $\kappa \mathrm{B}$ in HUVECs treated with TGF- $\beta 1$ in the absence or presence of EOFAZ, co-immunoprecipitation studies were performed. The results demonstrated that TGF- $\beta 1$ enhanced the binding between KLF4 and NF- $\mathrm{B}$, However, EOFAZ treatment reduced the TGF- $\beta 1$-induced interaction between KLF4 and NF- $\mathrm{B}$, although it was not determined if this effect was direct or indirect (Fig. 3E).

Effect of KLF4 siRNA transfection on KLF4 expression. Previously, it has been suggested that KLF4 serves an important role in EndMT, which is involved in the development and progression of cerebral cavernous malformations. However, to the best of our knowledge, whether the effect of EOFAZ on EndMT is mediated by KLF4 in HUVECs has not been assessed. To investigate the relationship between EOFAZ and KLF4, a KLF4-specific siRNA was utilized to knockdown the expression of KLF4 (Fig. 4A and B). The results demonstrated that the green fluorescence-labeled siRNA was successfully transferred into HUVECs, and western blotting analysis demonstrated that KLF4 expression was significantly reduced following transfection with KLF4 siRNA.
Effect of EOFAZ on TGF- $\beta 1$-induced HUVEC migration following KLF4-knockdown. To evaluate HUVEC migration following transfection with KLF4 siRNA, wound healing and Transwell assays were performed. The KLF4 expression was significantly downregulated by siRNA interference (Fig. 4A and B). As shown in Fig. 4C, KLF4-knockdown significantly reduced TGF- $\beta 1$-induced cell migration. Transwell assays revealed that the number of migrated cells was significantly decreased in the KLF4-knockdown cells compared with the TGF- $\beta 1$ group, and EOFAZ treatment decreased the number of migrated cells under TGF- $\beta 1$ stimulation (Fig. 4D). These results suggest that EOFAZ inhibition of TGF- $\beta 1$-mediated EndMT induction in HUVECs may occur through downregulation of KLF4 expression.

EOFAZ inhibits TGF- $\beta 1$-induced EndMT via KLF4. To determine the effect of KLF4 siRNA on EOFAZ-mediated inhibition of TGF- $\beta 1$-induced EndMT, the expression of $\alpha$-SMA and VE-cadherin was determined by immunofluorescence analysis. As presented in Fig. 5A, VE-cadherin expression was downregulated and $\alpha$-SMA expression was upregulated in the TGF- $\beta 1$ group. However, following KLF-knockdown and EOFAZ treatment, the effects on VE-cadherin and $\alpha$-SMA expression were reversed compared with the TGF- $\beta 1$-treated group. Furthermore, the expression 
A

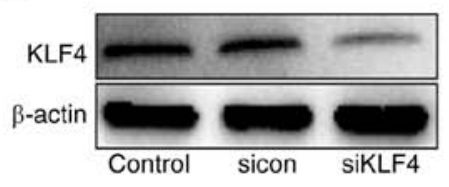

C
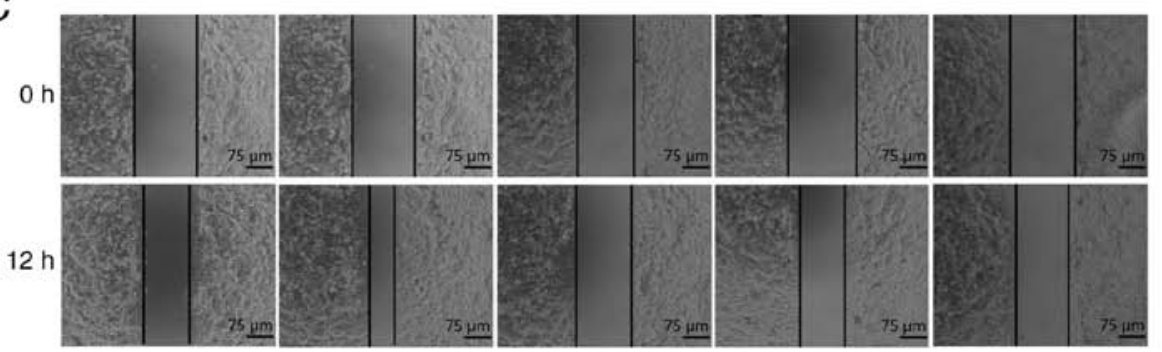

D

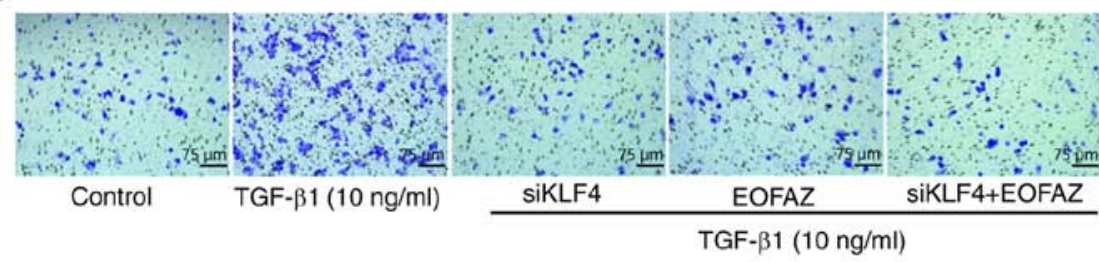

B

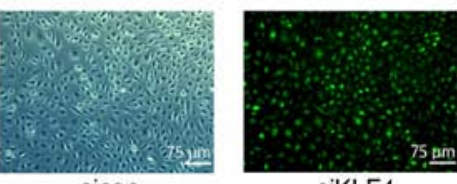

siKLF4

sicon

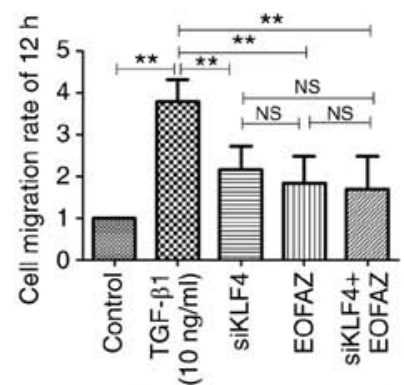

TGF- $\beta 1(10 \mathrm{ng} / \mathrm{ml})$

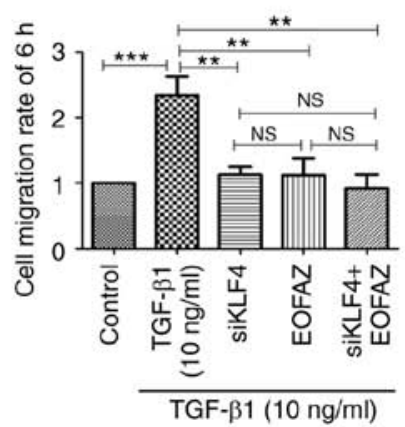

Figure 4. Effect of KLF4-knockdown on the migration in HUVECs. (A) The efficacy of siKLF4 transfection was measured by western blotting. (B) Fluorescence microscopy was used to observe whether green fluorescence-labeled siKLF4 was effectively transfected into the cells. Magnification, $x 100$. (C) Wound healing assay of HUVECs treated with TGF- $\beta 1$, EOFAZ and siKLF4. (D) Transwell assay of HUVECs treated with TGF- $\beta 1$, EOFAZ and siKLF4. $\mathrm{n}=5$. ${ }^{* *} \mathrm{P}<0.01$, ${ }^{* * * *} \mathrm{P}<0.001$. NS, not significant; TGF- $\beta 1$, transforming growth factor- $\beta 1$; HUVEC, human umbilical vein endothelial cell; siRNA, small interfering; KLF4, Krüppel-like factor 4; sicon, control small interfering RNA; siKLF4, KLF4 small interfering RNA; EOFAZ, essential oil from Alpinia zerumbet rhizome.

levels of $\alpha$-SMA, Snail, VE-cadherin and NF- $\mathrm{B}$ p-p65/p65 ratio were determined by western blotting, and $\alpha$-SMA, Snail, VE-cadherin were analyzed by RT-qPCR. Similar results were observed for the changes in VE-cadherin and $\alpha$-SMA expression. In addition, the Snail expression and NF- $\mathrm{BB}$ p-p65/p65 ratio levels were significantly repressed when exposed to siKLF and EOFAZ (Fig. 5B). Alterations in mRNA expression levels of VE-cadherin, $\alpha$-SMA and Snail were consistent with the western blotting (Fig. 5C). Together, these results demonstrated that KLF4-knockdown inhibited EndMT, and there were no significant differences between EOFAZ treatment and siKLF4 treatment. These results suggest that EOFAZ regulates EndMT via KLF4.

\section{Discussion}

Endothelial cells are highly sensitive to stimuli and physiological cues in the immediate environment (33). Thus, injury of the vascular endothelium is an initial step in the pathogenesis of vascular remodeling and contributes to vascular remodeling as a source of SM-like cells, as endothelial cells can acquire a fibro-proliferative mesenchymal phenotype through EndMT under specific pathological conditions, including shear stress, oxidative stress and atherosclerosis (34). The present study demonstrated that endothelial cells differentiate towards a SM-like phenotype via EndMT trans-differentiation when treated with TGF- $\beta 1$, and that the KLF4 signaling pathway was involved in this process. Additionally, it was shown that EOFAZ could inhibit TGF- $\beta 1$-induced EndMT via downregulation of KLF4.

EndMT is a newly recognized, fundamental biological process involved in development and tissue regeneration, as well as pathological processes, including certain complications of diabetes, fibrosis, PAH, atherosclerosis (35-38), tumor metastasis and development of fibrotic lesions in certain vital organs (32). EndMT is tightly controlled by a series of signaling networks, similar to the epithelial-to-mesenchymal transition (38). EndMT is involved in intima formation and pulmonary vascular angiogenesis (16) and may contribute to cardiac fibrosis (39); similar results have been observed in diabetes mellitus-induced cardiac fibrosis (40) and further studies confirmed that EndMT contributes to fibrogenesis associated with exposure to TGF- $\beta 1$ (41).

Consistent with these previous results, the present study demonstrated that HUVECs underwent phenotypic and biological behavioral transitions following TGF- $\beta 1$ exposure consistent with fibrogenesis. TGF- $\beta 1$ is involved in a wide range of pathological conditions, including a number of 

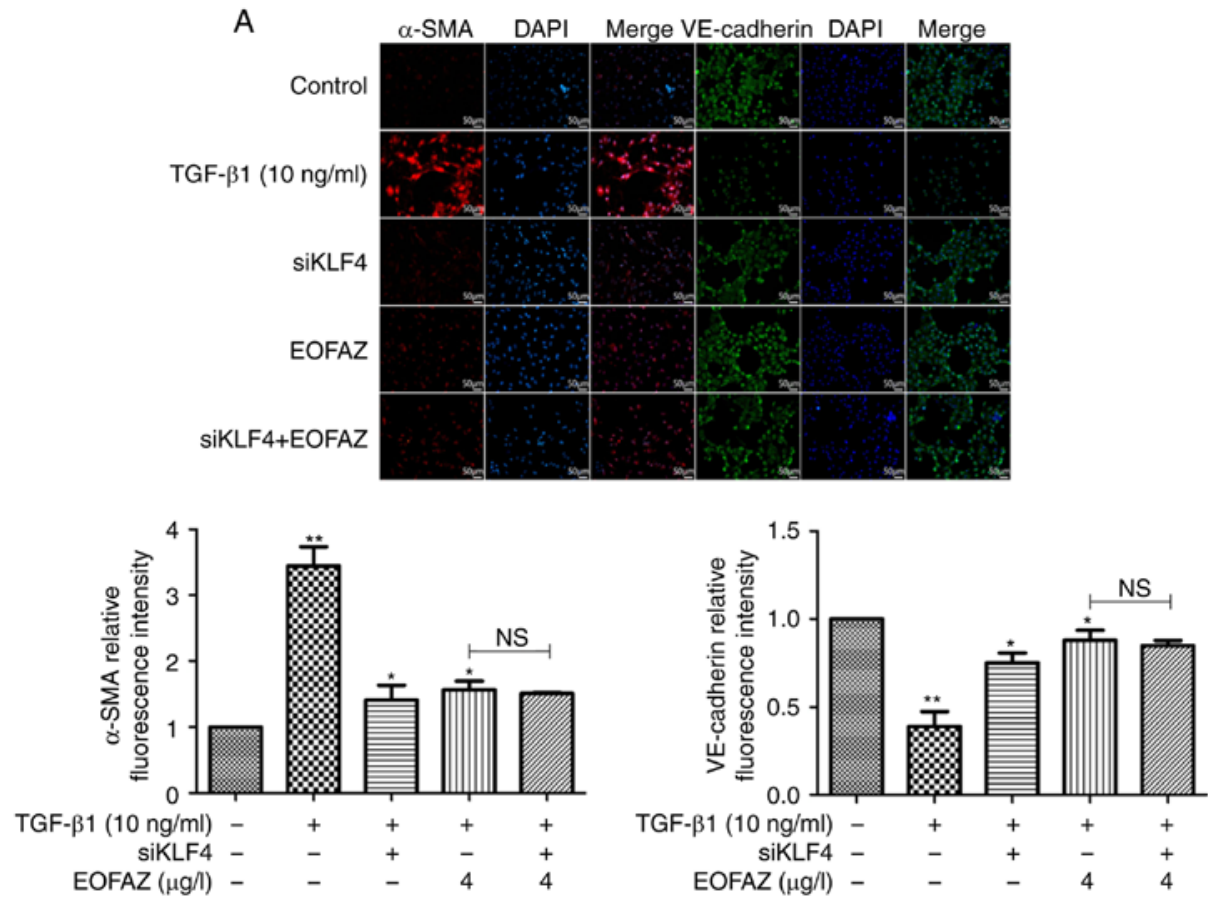

B
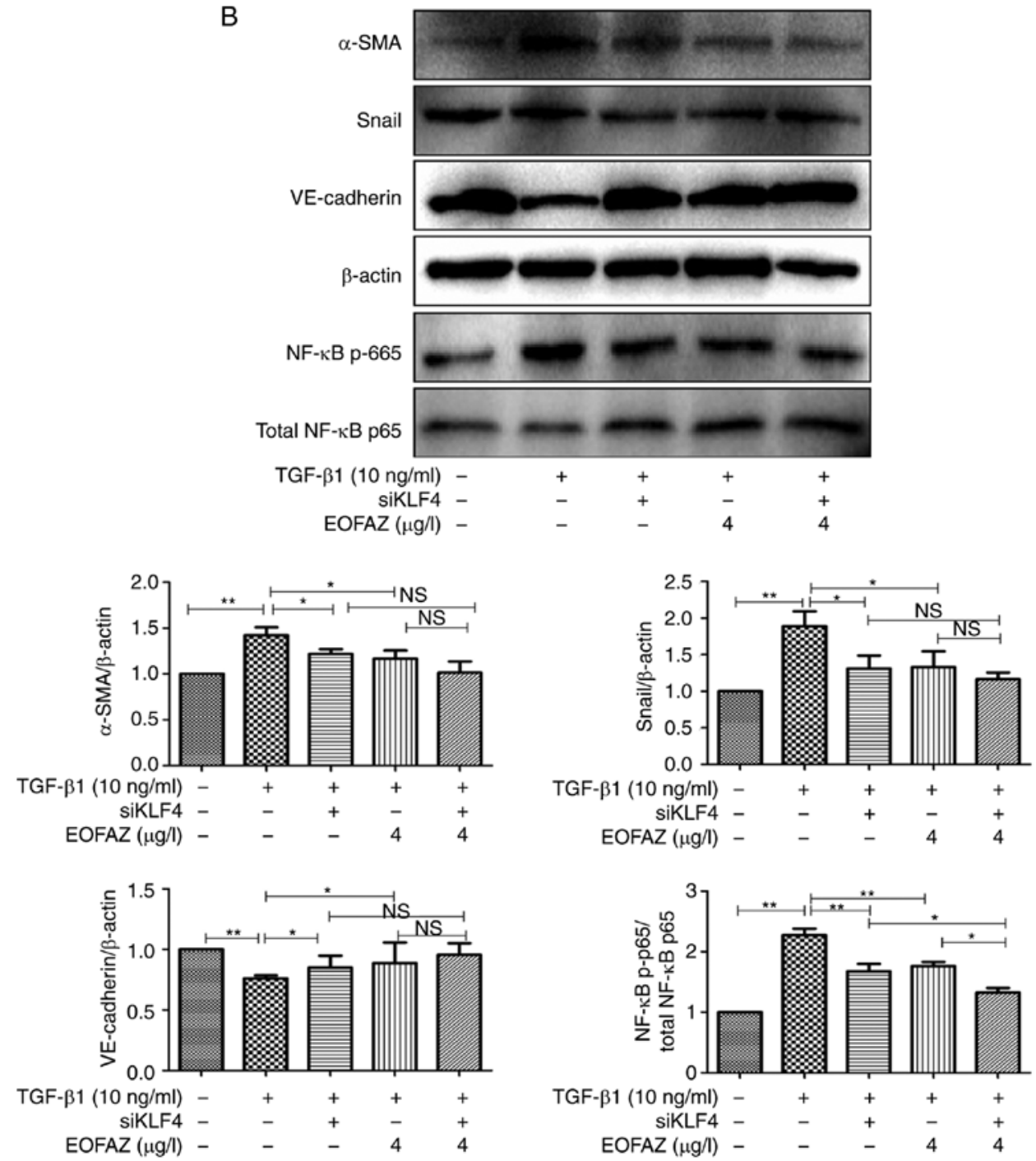

Figure 5. Effect of KLF4 knockdown on TGF- $\beta 1$-induced EndMT. (A) Effect of KLF4-knockdown on the expression levels of VE-cadherin and $\alpha$-SMA was assessed using immunofluorescence. Endothelial marker protein VE-cadherin (green fluorescence), mesenchymal marker protein $\alpha$-SMA (red fluorescence) and nuclei (DAPI, blue). Magnification, x200. (B) Effect of KLF4-knockdown on the expression of VE-cadherin, $\alpha$-SMA, NF- $\kappa B$ p-p65 and Snail were evaluated by western blotting. $\beta$-actin was used as the loading control. 


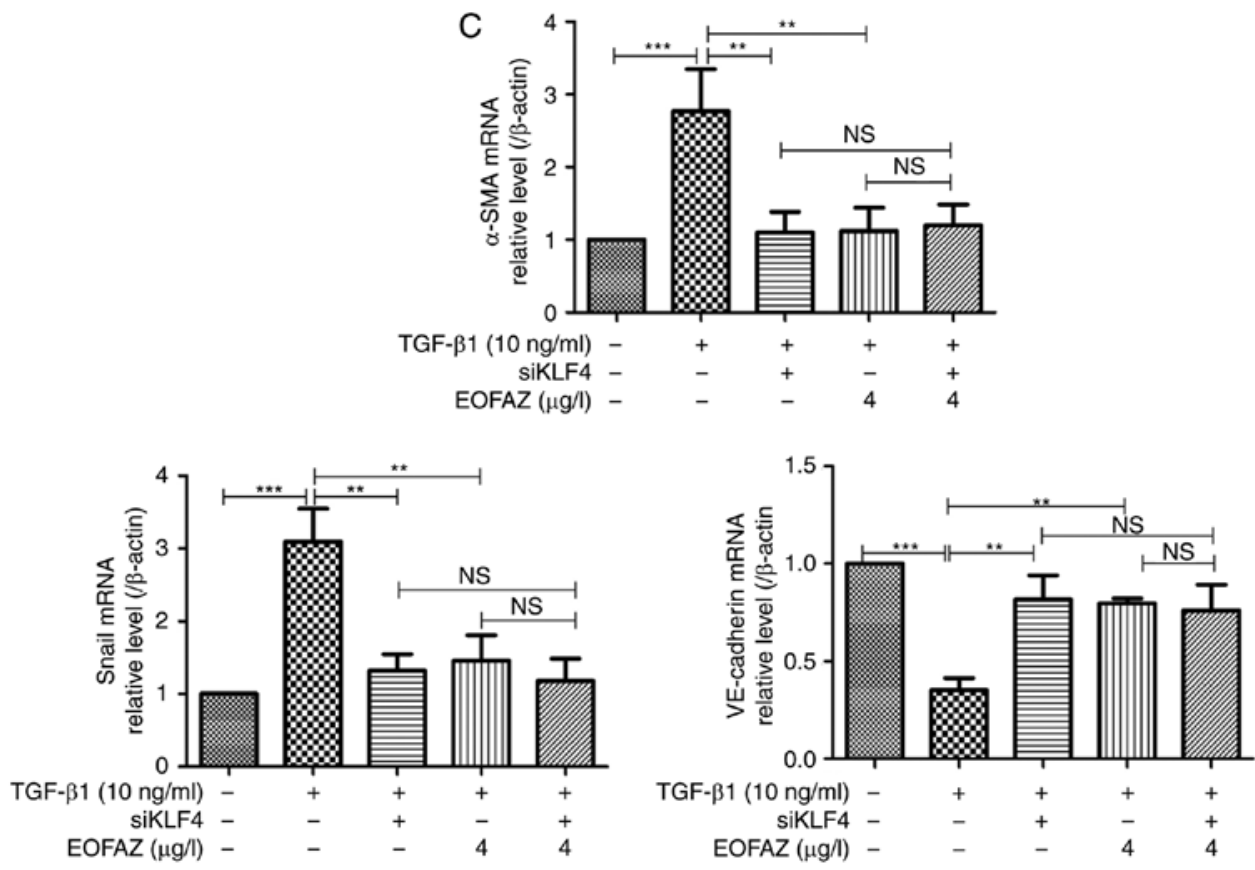

Figure 5. Continued. (C) Effect of KLF4-knockdown on mRNA expression levels of VE-cadherin and $\alpha$-SMA, normalized to $\beta$-actin. $n=5$. "P<0.05, "* $\mathrm{P}<0.01$, ${ }_{* * * *}^{*} \mathrm{P}<0.001$. NS, not significant; siKLF4, KLF4 small interfering RNA; p-, phosphorylated; KLF4, Krüppel-like factor 4; EOFAZ, essential oil from Alpinia zerumbet rhizome; N.S., not significant; TGF- $\beta 1$, transforming growth factor- $\beta 1$; $\alpha$-SMA, $\alpha$-smooth muscle actin; VE-cadherin, vascular endothelial-cadherin .

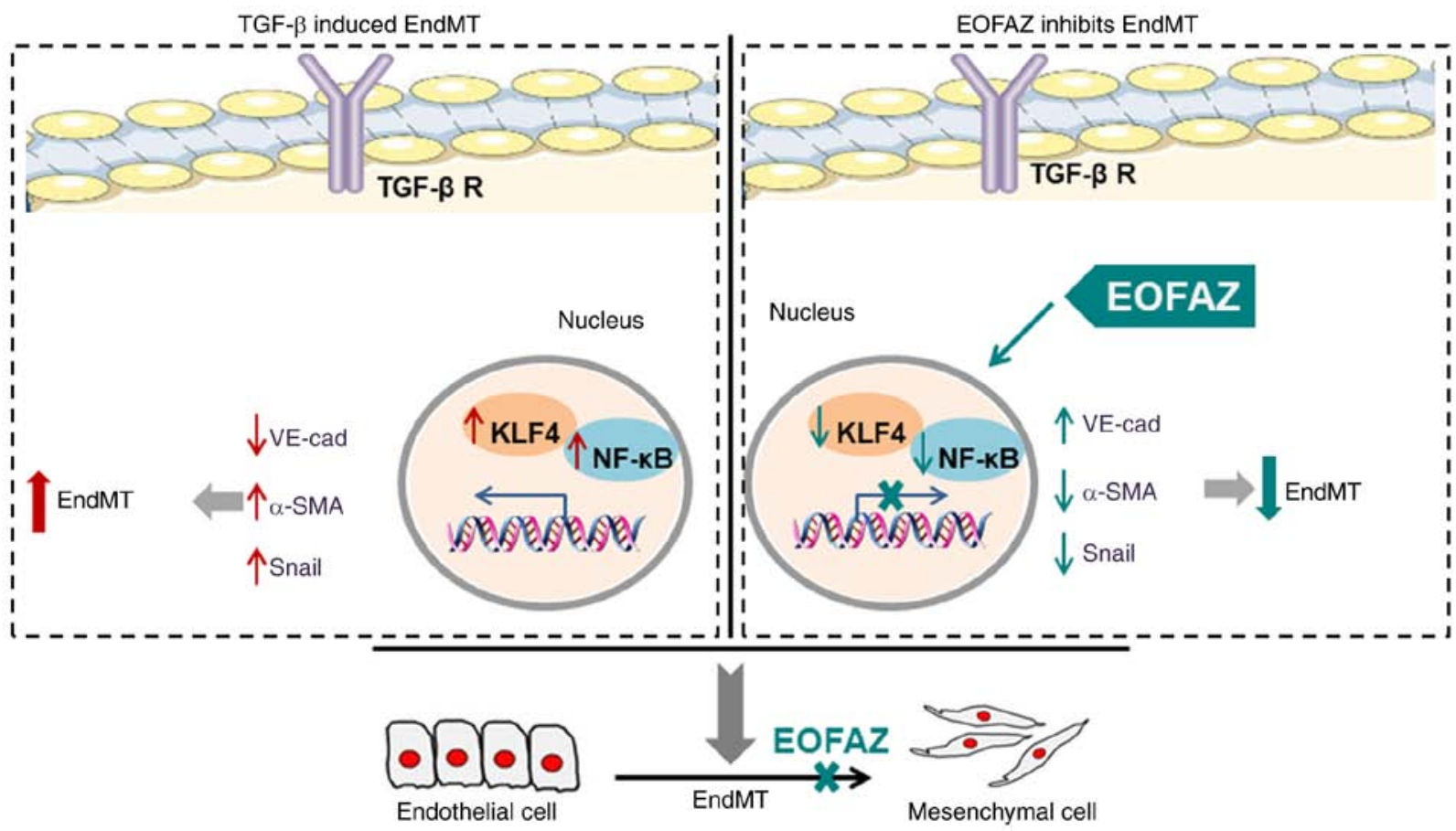

Figure 6. The inhibition effect of EOFAZ on TGF- $\beta 1$-induced EndMT. As a crucial factor for induction of EndMT, TGF- $\beta 1$ induces downregulation of the endothelial marker VE-cadherin and upregulation of the mesenchymal marker $\alpha$-SMA and Snail. In addition, TGF- $\beta 1$ enhances the binding between KLF4 and NF-кB. The present study identified that EOFAZ inhibits the migration of HUVECs upon TGF- $\beta 1$-induced EndMT via upregulating $\alpha$-SMA and Snail, and downregulating VE-cadherin. Furthermore, the mechanism research demonstrated that EOFAZ could decrease KLF4 expression and subsequently prevent the combination between KLF4 and NF-кB, which could suppress the activation of NF-кB, as well as the stimulation of TGF- $\beta 1$. EOFAZ, essential oil from Alpinia zerumbet rhizome; TGF- $\beta 1$, transforming growth factor- $\beta 1 ; \alpha$-SMA, $\alpha$-smooth muscle actin; VE-cadherin, vascular endothelial-cadherin; HUVEC, human umbilical vein endothelial cell; EndMT, endothelial-to-mesenchymal transition; TGF- $\beta$ R, transforming growth factor- $\beta$ receptor.

different types of cancer (42), myocardial infarction (43), cerebral cavernous malformations (44), vascular remolding and different types of organ fibrosis $(40,41)$. During this process, TGF- $\beta 1$ activates EndMT via multiple pathways including the canonical Smad-dependent and non-canonical Smad-independent pathways, and the bFGF, Wnt and Notch signaling pathways (45). A previous study has demonstrated the contribution of TGF- $\beta 1$ to EndMT in the regulation of 
cardiovascular diseases (46). Therefore, any potential target to inhibit or reduce TGF- $\beta 1 /$ Snail signaling may exhibit potential as an anti-proliferative reagent. The present study demonstrated that TGF- $\beta 1$ treatment increased the expression of Snail, $\alpha-S M A$ and NF- $\kappa$ B p-p65/p65 ratio, and reduced the expression of VE-cadherin, suggesting that TGF- $\beta 1$ can induce EndMT. Treatment with EOFAZ inhibited TGF- $\beta 1$-mediated induction of EndMT. Additionally, the increases in Snail and $\alpha$-SMA expression and NF- $\kappa \mathrm{B}$ p-p65/p65 ratio in TGF- $\beta 1$-treated cells were significantly decreased following treatment with EOFAZ. These results suggest that EOFAZ may be a promising agent for ameliorating EndMT-related diseases.

KLF4 is an evolutionarily conserved zinc finger-containing transcription factor and is widely expressed in a range of tissues where it regulates a range of cellular processes, including cell growth, proliferation and differentiation (47). KLF4 has a critical regulatory effect on a range of functions, including maintaining intestinal epithelial homeostasis, proliferation, migration and tube formation in human retinal microvascular endothelial cells, and inhibiting NF- $\mathrm{NB}$ transcriptional activity and the expression of downstream prothrombotic, proinflammatory genes (48-51). KLF4 mediates an increase in the lesions and the pseudo-normal vasculature of endothelial-specific CCM1-knockout mice (32). KLF4 also regulates VE-cadherin expression and endothelial barrier function, angiogenesis via the Notch signaling pathway, vascular tone and permeability, apoptosis, inflammation and atherothrombosis (50). KLF4 can contribute to epithelial-mesenchymal transition during the development and progression of cancer (51). Additionally, previous studies have shown that KLF4 is involved in EndMT in cerebral cavernous malformations (47). In the present study, the results demonstrated that KLF4 was excessively activated during TGF- $\beta 1$ exposure, which resulted in the increase in the degree of EndMT in HUVECs. KLF4-knockdown inhibited EndMT and decreased the protein and mRNA expression levels of Snail and $\alpha$-SMA. whilst increased VE-cadherin expression. Following treatment with EOFAZ, the processes associated with EndMT were reversed. These results suggest that EOFAZ may inhibit TGF- 31 -induced EndMT through inhibition of KLF4.

In conclusion, EOFAZ significantly inhibited the extent of EndMT following TGF- $\beta 1$ exposure, a protective effect that was mediated through reduction in KLF4 activity. In sum, a graphical abstract is proposed and presented in Fig. 6, which summarizes the whole investigation. The results of the present study contribute to the understanding of the molecular mechanisms underlying EndMT and reveal novel targets, which may be the basis of potential therapeutic strategies.

\section{Acknowledgements}

The authors wish to thank Dr Di Pan (The State Key Laboratory of Functions and Applications of Medicinal Plants, School of Pharmaceutical Sciences, Guizhou Medical University, Guiyang, China) for their kind linguistic advice and technical assistance.

\section{Funding}

This study was supported by the National Natural Science Foundation of China (grant nos. 81560811, 81760725 and
U1812403-4-4), the Guizhou Provincial Key Technology R\&D Program [grant no. (2020)4Y093], the Scientific and Technological Founding of Guizhou Province [grant no. QKHJ (2016)1128], the Foundation of Science and Technology Department Cooperation Program of Guizhou Province (grant no. 2016-7358) and Guizhou Graduate Research (grant no. 0711007020259).

\section{Availability of data and materials}

The datasets used and/or analyzed during the present study are available from the corresponding author on reasonable request.

\section{Authors' contributions}

YZ performed part of the experiments and wrote the manuscript. CL performed the experiments. YH designed the study and analyzed the data. SZ performed the experiments. YX and YC analyzed the data. FJ and LT extracted the essential oil. XS designed the experiment and revised the manuscript. All authors read and approved the final manuscript.

\section{Ethics approval and consent to participate}

Not applicable.

\section{Patient consent for publication}

Not applicable.

\section{Competing interests}

The authors declare that they have no competing interests.

\section{References}

1. Chen Q, Zhang H, Liu Y, Adams S, Eilken H, Stehling M, Corada M, Dejana E, Zhou B and Adams RH: Endothelial cells are progenitors of cardiac pericytes and vascular smooth muscle cells. Nat Commun 7: 12422, 2016.

2. Gibbons GH and Dzau VJ: The emerging concept of vascular remodeling. N Engl J Med 330: 1431-1438, 1994.

3. Davis GE and Senger DR: Endothelial extracellular matrix: Biosynthesis, remodeling, and functions during vascular morphogenesis and neovessel stabilization. Circ Res 97: 1093-1107, 2005.

4. Karimi Galougahi K, Ashley EA and Ali ZA: Redox regulation of vascular remodeling. Cell Mol Life Sci 73: 349-363, 2016.

5. Zhang B, Niu W, Dong HY, Liu ML, Luo Y and Li ZC: Hypoxia induces endothelial-mesenchymal transition in pulmonary vascular remodeling. Int J Mol Med 42: 270-278, 2018.

6. Jackson AO, Zhang J, Jiang Z and Yin K: Endothelial-tomesenchymal transition: A novel therapeutic target for cardiovascular diseases. Trends Cardiovasc Med 27: 383-393, 2017.

7. Zhang L, Li YM, Zeng XX, Wang XY, Chen SK, Gui LX and Lin MJ: Galectin-3-mediated transdifferentiation of pulmonary artery endothelial cells contributes to hypoxic pulmonary vascular remodeling. Cell Physiol Biochem 51: 763-777, 2018.

8. Wesseling M, Sakkers TR, de Jager SCA, Pasterkamp G and Goumans MJ: The morphological and molecular mechanisms of epithelial/endothelial-to-mesenchymal transition and its involvement in atherosclerosis. Vascul Pharmacol 106: 1-8, 2018.

9. Zhang Y, Wu X, Li Y, Zhang H, Li Z, Zhang Y, Zhang L, Ju J, Liu X, Chen X, et al: Endothelial to mesenchymal transition contributes to arsenic-trioxide-induced cardiac fibrosis. Sci Rep 6,33787, 2016.

10. Tian D, Zeng X, Wang W, Wang Z, Zhang Y and Wang Y: Protective effect of rapamycin on endothelial-to-mesenchymal transition in HUVECs through the Notch signaling pathway. Vascul Pharmacol 113: 20-26, 2018. 
11. Kanasaki K, Taduri G and Koya D: Diabetic nephropathy: The role of inflammation in fibroblast activation and kidney fibrosis. Front Endocrinol (Lausanne) 4: 7, 2013.

12. Xiong J, Kawagishi H, Yan Y, Liu J, Wells QS, Edmunds LR, Fergusson MM, Yu ZX, Rovira II, Brittain EL, et al: A metabolic basis for endothelial-to-mesenchymal transition. Mol Cell 69: 689-698.e7, 2018.

13. Yu QC, Song W, Wang D and Zeng YA: Identification of blood vascular endothelial stem cells by the expression of protein $\mathrm{C}$ receptor. Cell Res 26: 1079-1098, 2016.

14. Cooley BC, Nevado J, Mellad J, Yang D, St Hilaire C, Negro A, Fang F, Chen G, San H, Walts AD, et al: TGF- $\beta$ signaling mediates endothelial-to-mesenchymal transition (EndMT) during vein graft remodeling. Sci Transl Med 6: 227ra34, 2014

15. Vanchin B, Offringa E, Friedrich J, Brinker MG, Kiers B, Pereira AC, Harmsen MC, Moonen JA and Krenning G: MicroRNA-374b induces endothelial-to-mesenchymal transition and early lesion formation through the inhibition of MAPK7 signaling. J Pathol 247: 456-470, 2019.

16. Suzuki T, Carrier EJ, Talati MH, Rathinasabapathy A, Chen X, Nishimura R, Tada Y, Tatsumi $\mathrm{K}$ and West J: Isolation and characterization of endothelial-to-mesenchymal transition cells in pulmonary arterial hypertension. Am J Physiol Lung Cell Mol Physiol 314: L118-L126, 2018.

17. Li J, Xiong J, Yang B, Zhou Q, Wu Y, Luo H, Zhou H, Liu N, Li Y, Song Z and Zheng Q: Endothelial cell apoptosis induces TGF- $\beta$ signaling-dependent host endothelial-mesenchymal transition to promote transplant arteriosclerosis. Am J Transplant 15 : 3095-3111, 2015.

18. Wang J, Yan G, Guo H, Zhu Y, Shui X, He Y, Chen C and Lei W: ITE promotes hypoxia-induced transdifferentiation of human pulmonary arterial endothelial cells possibly by activating transforming growth factor- $\beta /$ Smads and MAPK/ERK pathways J Cell Biochem 120: 19567-19577, 2019.

19. Zuo XX, Yang Y, Zhang Y, Zhang ZG, Wang XF and Shi YG: Platelets promote breast cancer cell MCF-7 metastasis by direct interaction: Surface integrin $\alpha 2 \beta 1$-contacting-mediated activation of Wnt- $\beta$-catenin pathway. Cell Commun Signal 17: 142, 2019.

20. Shen XC, Tao L, Li WK, Zhang YY, Luo H and Xia YY: Evidence-based antioxidant activity of the essential oil from fructus A. Zerumbet on cultured human umbilical vein endothelial cells' injury induced by ox-LDL. BMC Complement Altern Med 12: 174, 2012.

21. Tao L, Hu HS and Shen XC: Endothelium-dependent vasodilatation effects of the essential oil from Fructus alpiniae zerumbet (EOFAZ) on rat thoracic aortic rings in vitro. Phytomedicine 20: 387-393, 2013

22. Chen Y, Li D, Xu Y, Zhang Y, Tao L, Li S, Jiang Y and Shen X: Essential oils from fructus A. Zerumbet protect human aortic endothelial cells from apoptosis induced by Ox-LDL in vitro. Evid Based Complement Alternat Med 2014: 956824, 2014.

23. Yob NJ, Jofrry SM, Affandi MM, The LK, Salleh MZ and Zakaria ZA: Zingiber zerumbet (L.) Smith: A review of its ethnomedicinal, chemical, and pharmacological uses. Evid Based Complement Alternat Med 2011: 543216, 2011.

24. Chompoo J, Upadhyay A, Fukuta M and Tawata S: Effect of Alpiniazerumbet components on antioxidant and skin diseases-related enzymes. BMC Complement Altern Med 12: 106, 2012.

25. de Moura RS, Emiliano AF, de Carvalho LC, Souza MA, Guedes DC, Tano T and Resende AC: Antihypertensive and endothelium-dependent vasodilator effects of Alpinia zerumbet, a medicinal plant. J Cardiovasc Pharmacol 46: 288-294, 2005.

26. Linghu K, Lin D, Yang H, Xu Y, Zhang Y, Tao L, Chen Y and Shen X: Ameliorating effects of 1,8-cineole on LPS-induced human umbilical vein endothelial cell injury by suppressing NF- $\kappa$ B signaling in vitro. Eur J Pharmacol 789: 195-201, 2016.

27. Yang H, Fang Z, Qu X, Zhang X and Wang Y: Procyanidin compound (PC) suppresses lipopolysaccharide-induced cervical cancer cell proliferation through blocking the TLR4/NF- $\kappa \mathrm{B}$ pathway. Cancer Manag Res 12: 497-509, 2020.

28. Shu Y, Liu Y, Li X, Cao L, Yuan X, Li W and Cao Q Aspirin-triggered resolvin D1 inhibits TGF- $\beta 1$-induced EndMT through increasing the expression of Smad7 and is closely related to oxidative stress. Biomol Ther (Seoul) 24: 132-139, 2016.

29. Mahler GJ, Farrar EJ and Butcher JT: Inflammatory cytokines promote mesenchymal transformation in embryonic and adult valve endothelial cells. Arterioscler Thromb Vasc Biol 33: 121-130, 2013

30. Yoshida T, Yamashita M, Iwai M and Hayashi M: Endothelial Krüppel-like factor 4 mediates the protective effect of statins against ischemic AKI. J Am Soc Nephrol 27: 1379-1388, 2016.
31. Cuttano R, Rudini N, Bravi L, Corada M, Giampietro C, Papa E, Morini MF, Maddaluno L, Baeyens N, Adams RH, et al: KLF4 is a key determinant in the development and progression of cerebral cavernous malformations. EMBO Mol Med 8: 6-24, 2016.

32. Zhou Z, Tang AT, Wong WY, Bamezai S, Goddard LM, Shenkar R, Zhou S, Yang J, Wright AC, Foley M, et al: Cerebral cavernous malformations arise from endothelial gain of MEKK3-KLF2/4 signalling. Nature 532: 122-126, 2016.

33. Huang N, Xu Y, Zhou H, Lin D, Zhang B, Zhang Y, Pan D, Tao L, Liu $X$ and Shen $X$ : Essential oil from fructus alpiniae zerumbet protects human umbilical vein endothelial cells in vitro from injury induced by high glucose levels by suppressing nuclear transcription factor-kappa B signaling. Med Sci Monit 23: 4760-4767, 2017.

34. Wu M, Liu L, Xing Y, Yang S, Li H and Cao Y: Roles and mechanisms of hawthorn and its extracts on atherosclerosis: A review. Front Pharmacol 11: 118, 2020.

35. Yu W, Liu Z, An S, Zhao J, Xiao L, Gou Y, Lin Y and Wang J: The endothelial-mesenchymal transition (EndMT) and tissue regeneration. Curr Stem Cell Res Ther 9: 196-204, 2014

36. Cruz-Solbes AS and Youker K: Epithelial to mesenchymal transition (EMT) and endothelial to mesenchymal transition (EndMT): Role and implications in kidney fibrosis. Results Probl Cell Differ 60: 345-372, 2017.

37. Pardali E, Sanchez-Duffhues G, Gomez-Puerto MC and Ten Dijke P: TGF- $\beta$-induced endothelial-mesenchymal transition in fibrotic diseases. Int J Mol Sci 18: pii: E2157, 2017.

38. Hao YM, Yuan HQ, Ren Z, Qu SL, Liu LS, Dang H, Yin K, Fu M and Jiang ZS: Endothelial to mesenchymal transition in atherosclerotic vascular remodeling. Clin Chim Acta 490: 34-38, 2019.

39. Geng $\mathrm{H}$ and Guan J: MiR-18a-5p inhibits endothelial-mesenchymal transition and cardiac fibrosis through the Notch2 pathway. Biochem Biophys Res Commun 491: 329-336, 2017.

40. Chen XY, Lv RJ, Zhang W, Yan YG, Li P, Dong WQ, Liu X, Liang ES, Tian HL, Lu QH and Zhang MX: Inhibition of myocyte-specific enhancer factor $2 \mathrm{~A}$ improved diabetic cardiac fibrosis partially by regulating endothelial-to-mesenchymal transition. Oncotarget 7: 31053-31066, 2016.

41. Guan S and Zhou J: CXCR7 attenuates the TGF- $\beta$-induced endothelial-to-mesenchymal transition and pulmonary fibrosis. Mol Biosyst 13: 2116-2124, 2017.

42. Akhurst RJ: Targeting TGF- $\beta$ signaling for therapeutic gain. Cold Spring Harb Perspect Biol 9: pii: a022301, 2017.

43. Bakhta O, Blanchard S, Guihot AL, Tamareille S, MirebeauPrunier D, Jeannin P and Prunier F: Cardioprotective role of colchicine against inflammatory injury in a rat model of acute myocardial infarction. J Cardiovasc Pharmacol Ther 23: 446-455, 2018.

44. Wetzel-Strong SE, Detter MR and Marchuk DA: The pathobiology of vascular malformations: Insights from human and model organism genetics. J Pathol 241: 281-293, 2017.

45. Fu Y, Chang A, Chang L, Niessen K, Eapen S, Setiadi A and Karsan A: Differential regulation of transforming growth factor beta signaling pathways by Notch in human endothelial cells. J Biol Chem 284: 19452-19462, 2009.

46. Cunha SI, Magnusson PU, Dejana E and Lampugnani MG: Deregulated TGF- $\beta$ /BMP signaling in vascular malformations. Circ Res 121: 981-999, 2017.

47. Ghaleb AM and Yang VW: Krüppel-like factor 4 (KLF4): What we currently know. Gene 611: 27-37, 2017.

48. McConnell BB, Ghaleb AM, Nandan MO and Yang VW: The diverse functions of Krüppel-like factors 4 and 5 in epithelial biology and pathobiology. Bioessays 29: 549-557, 2007.

49. Zhang Y, Lam O, Nguyen MT, Ng G, Pear WS, Ai W, Wang IJ, Kao WW and Liu CY: Mastermind-like transcriptional co-activator-mediated Notch signaling is indispensable for maintaining conjunctival epithelial identity. Development 140: 594-605, 2013.

50. Wang Y, Yang C, Gu Q, Sims M, Gu W, Pfeffer LM and Yue J: KLF4 promotes angiogenesis by activating VEGF signaling in human retinal microvascular endothelial cells. PLoS One 10: e0130341, 2015.

51. Ji L, Zhao G, Zhang P, Huo W, Dong P, Watari H, Jia L, Pfeffer LM, Yue J and Zheng J: Knockout of MTF1 inhibits the epithelial to mesenchymal transition in ovarian cancer cells. J Cancer 9: 4578-4585, 2018.

This work is licensed under a Creative Commons Attribution-NonCommercial-NoDerivatives 4.0 International (CC BY-NC-ND 4.0) License. 